\title{
Climatic classification and future global redistribution of agricultural land
}

\author{
Wolfgang P. Cramer ${ }^{1}$, Allen M. Solomon ${ }^{2}$ \\ ${ }^{1}$ Potsdam Institute for Climate Impact Research, Telegrafenburg, D-14473 Potsdam, Germany \\ ${ }^{2}$ Environmental Research Laboratory, U.S. Environmental Protection Agency, 200 SW 35th St., Corvallis, Oregon 97333, USA
}

\begin{abstract}
Future global carbon (C) cycle dynamics under climates altered by increased concentrations of greenhouse gases (GHGs) will be defined in part by processes which control terrestrial biospheric $C$ stocks and fluxes. Current research and modeling activities which involve terrestrial $C$ have focused on the response of unmanaged vegetation to changing climate and atmospheric chemistry. A common conclusion reached from applying geographically explicit terrestrial carbon models is that more $\mathrm{C}$ would be stored by equilibrium vegetation controlled by a stable GHG-warmed climate than by equilibrium vegetation under the current (stable) climate. We examined the potential impact on the terrestrial C cycle if global agriculture were to increase to the limits permitted by future GHG-induced climates. Climatic limits to global agricultural zones were determined, the new climatic limits to agricultural zones projected, and the amount of $\mathrm{C}$ the terrestrial biosphere would store under the new climate and agricultural conditions was calculated. We conclude that following a warming loss of $\mathrm{C}$ from agriculture could be as important as gain of $\mathrm{C}$ by climate effects. As much or less $\mathrm{C}$ would be stored by a terrestrial biosphere in which agriculture reached its new climatic limits as is stored by the current biosphere in which agriculture reaches its climatic limits. We project that agriculture alone could produce a $\mathrm{C}$ source of 0.3 to $1.7 \mathrm{Pg} \mathrm{yr}^{-1}$ if doubling of GHGs required 50 to $100 \mathrm{yr}$. The gains in agriculture would occur almost entirely in the developed countries of high latitudes, and the losses, in the less developed countries of the lower latitudes.
\end{abstract}

\section{INTRODUCTION}

Current concern is focused on the consequences of changing climate and atmospheric chemistry on the functioning of global ecosystems. That climate may change seems less relevant to human life and activity until one realizes that the ecological systems of the world (both natural and agroecosystems) are largely dependent upon the climatic status quo. Then, it becomes obvious that accurate predictions of biospheric response to changing climate and atmospheric chemistry are the essential basis for decision making on policies designed to ameliorate or avoid climate change effects (IPCC 1992).

In addition to their role in human well-being, global ecosystem responses must be predicted to define their future role in the global carbon (C) cycle (Solomon \& Cramer 1993). Some processes and regions act to store additional C (e.g. Solomon 1986) while others act to emit C from the biosphere (e.g Trabalka \& Reichle 1986). At present, the terrestrial biosphere may be anything from a significant net source of $\mathrm{C}$ which would amplify present and future warming (Houghton \& Woodwell 1989) to a significant net sink which would reduce present and future warming (Tans et al. 1990). The role of agricultural land uses in reducing $C$ storage is important today (e.g. Clark et al. 1986) and seems likely to be more important in the future if population continues its 35 to $40 \mathrm{yr}$ doubling rate and warming increases the area of arable land in high latitudes.

Research aimed at defining and predicting vegetation response to climate change is an active field. Several innovative contributions to predicting the transient dynamics and/or geographic distribution of global-scale vegetation response have been published or submitted recently (e.g. Prentice et al. 1993a, Neilson et al. 1993, Smith \& Shugart 1993). Generally, 
the objectives of the models fall into 2 distinct areas (Prentice \& Solomon 1990): dynamic models which abstract mechanistic processes and projections of future climate to predict changing temporal distributions of vegetation, and static models which use coincidence of geographic distributions of climate and vegetation with future climate projections to predict changing spatial distributions of vegetation.

Most of the dynamic models in use (e.g. Solomon 1986, Prentice et al. 1992b, 1993a) build upon the initial gap model approach developed by Botkin et al. (1972). These models use mechanistic relationships between environmental forcing, and physiological response at the level of forest stands, to follow the temporal succession of tree establishment, growth, and mortality in the continuous competition for sunlight. Thus, the models can predict lagged effects of rapid climate change, induced in particular by the slow growth to reproduction of long-lived trees. Detailed knowledge and data on life histories of individual species are required to parameterize the models, precluding their use to date in globally comprehensive model projections.

The more common static models generally project future vegetation distribution from climate predictions or scenarios generated by circulation models of the global atmosphere. The climate estimates are transformed into vegetation responses from correlations between geographic data sets on physical environmental variables (climate, soils, landforms) and data sets on vegetation classes (species, e.g. Cook \& Cole 1991, Davis \& Zabinski 1992; plant functional types, e.g. Box 1981, Cramer \& Leemans 1993; ecosystems, e.g. Neilson 1987, Sargent 1988; biomes, e.g. Emanuel et al. 1985, Prentice et al. 1992a; physiognomic types, e.g. Woodward 1987, Neilson et al. 1993).

It is important to emphasize that these models provide only one half of the information sought by their application. They illustrate the regions where current mutually exclusive combinations of vegetation and climate co-occur in the future, and hence, where current vegetation classes must deteriorate and disappear. As a rule, the models are incapable of accurately projecting the vegetation which would replace the vulnerable classes because the models do not consider the successional and migrational lags inherent in each wildland species. These lags define the rate at which new species and communities can appear in a region and become established and reproduce there.

A possible exception to this rule involves climate effects on the distribution of agroecosystems (Rosenberg 1982). Some workers expect agriculture to adjust within a few growing seasons to shifting boundaries of climatic limits to agronomic crop growth, both by the harvest of crop varieties in newly available regions in which they have never been successful (Decker et al. 1988, Parry \& Carter 1988) and by the development of new crop varieties which can thrive under previously hostile conditions (Crosson 1989, Rosenberg 1991). Here, both the losses by one set of agronomic crops and the gains by introduction of different crops in a region can be estimated with some degree of confidence (e.g. Leemans \& Solomon 1993, this volume, p. 79-96). There still seems to be no means to predict the role in future agriculture of increasing agricultural technology, or the genetic innovations in crop varieties.

Analysis reported in this paper estimates future shifts in global terrestrial carbon stocks based on static models that include both natural and agricultural systems. The estimates are derived from the Biome model of Prentice et al. (1992a), modified by the presence of a climate envelope within which current non-irrigated agriculture is confined. The specific objectives of this analysis are 2-fold: (1) estimate the difference between current potential agricultural land area and the area which will be available for farming because of predicted changes in global climate, and (2) explore the implications of the projected changes in agricultural area to the global balance between $\mathrm{C}$ storage and release.

\section{METHODS}

Global vegetation model. The Biome model was described by Prentice et al. (1992a) and only its relevant characteristics will be reviewed here. The model uses soil properties and climate to select the plant functional types (PFTs) which can occur in any terrestrial, ice-free location on the globe. The initial climate data sets were gridded at $0.5 \times 0.5$ degrees of latitude and longitude, although any scale of climate data distributions can be used (Leemans \& Cramer 1991). The climatic requirements for each PFT were defined as a minimal set of threshold values gathered from the ecophysiological literature.

The parameters used differ from one PFT to another, allowing more than one PFT to occupy the same climate space. Certain PFTs which climate allows to grow together do not coexist, however, because of competitive exlusion directed by differences in productivity. This is formalized as a dominance hierarchy, defining which PFTs will outcompete others. Thus, for example, conifers will be outcompeted and disappear where climate allows growth of both warm-temperate evergreens and cool-temperate conifers.

The set of PFTs which can occur in a given region define the 'Biomes' which will occupy the region. In some cases, only one PFT defines the Biome (e.g. tropical rain forest from tropical evergreen PFT), while in other 
cases, the coexistence of multiple PFTs are needed (e.g. taiga consists of a boreal evergreen conifer PFT plus a boreal summergreen PFT). Unlike most other vegetation-oriented climate classifications, the definition of PFTs as entities with overlapping niches, and Biomes as free associations among PFTs, allows the Biome model to recombine PFTs to form Biomes not found on the modern landscape. This property is in keeping with the documented propensity of biomes (specified combinations of species and genera) to assemble and disassemble, as has occurred over the space of a few millennia in the past (e.g. Webb 1987 , Overpeck et al. 1991), and with the likelihood that biomes will be required to do so in shorter periods under global warming in the future.

Agricultural component of global vegetation model. For this study of both the natural and landuse induced distribution of global vegetation, we sought a set of climate variables which could reproduce the geographic pattern created by the agricultural areas defined by Olson et al. (1983). These had been excluded from the Biome model (Fig. 1). Olson et al. subdivided their agricultural vegetation complexes from within a single 'agriculture' land class in a digitized land cover map by Hummel \& Reck
(1979). These authors, in turn, had taken their agricultural land from the map of 'Arable and mixed farming land (intensive farming)' in the Oxford World Atlas (e.g. map 99 of Cohen 1973). The original intent of the atlas was to define land which is under intensive agriculture. However, Hummel \& Reck, and later Olson et al., mapped croplands over considerably greater area than did Cohen. For example, using a strict definition of arable land, FAO (1986) estimated that $15 \times 10^{6} \mathrm{~km}^{2}$ of land was used for actually growing crops in 1984; Olson et al. estimated all agricultural lands at $25.12 \times 10^{6} \mathrm{~km}^{2}$.

Examination of geographical information system (GIS)-generated maps of measured and derived variables of global climate (Leemans \& Cramer 1991), in comparison to the Olson et al. agriculture map, revealed fairly simple but robust parallel distributions, particularly in the temperate agriculture belts. The high-latitude cold boundary of agricultural land coincides with the isotherm for 2000 growing degree days (GDD, $0^{\circ} \mathrm{C}$ base; Fig. 1). The match is fairly precise on all continents. Apparently, fewer than 2000 accumulated heat units during the growing season is too little to support intensive agriculture. Previous exercises in fitting forest borders to climate variables in the same

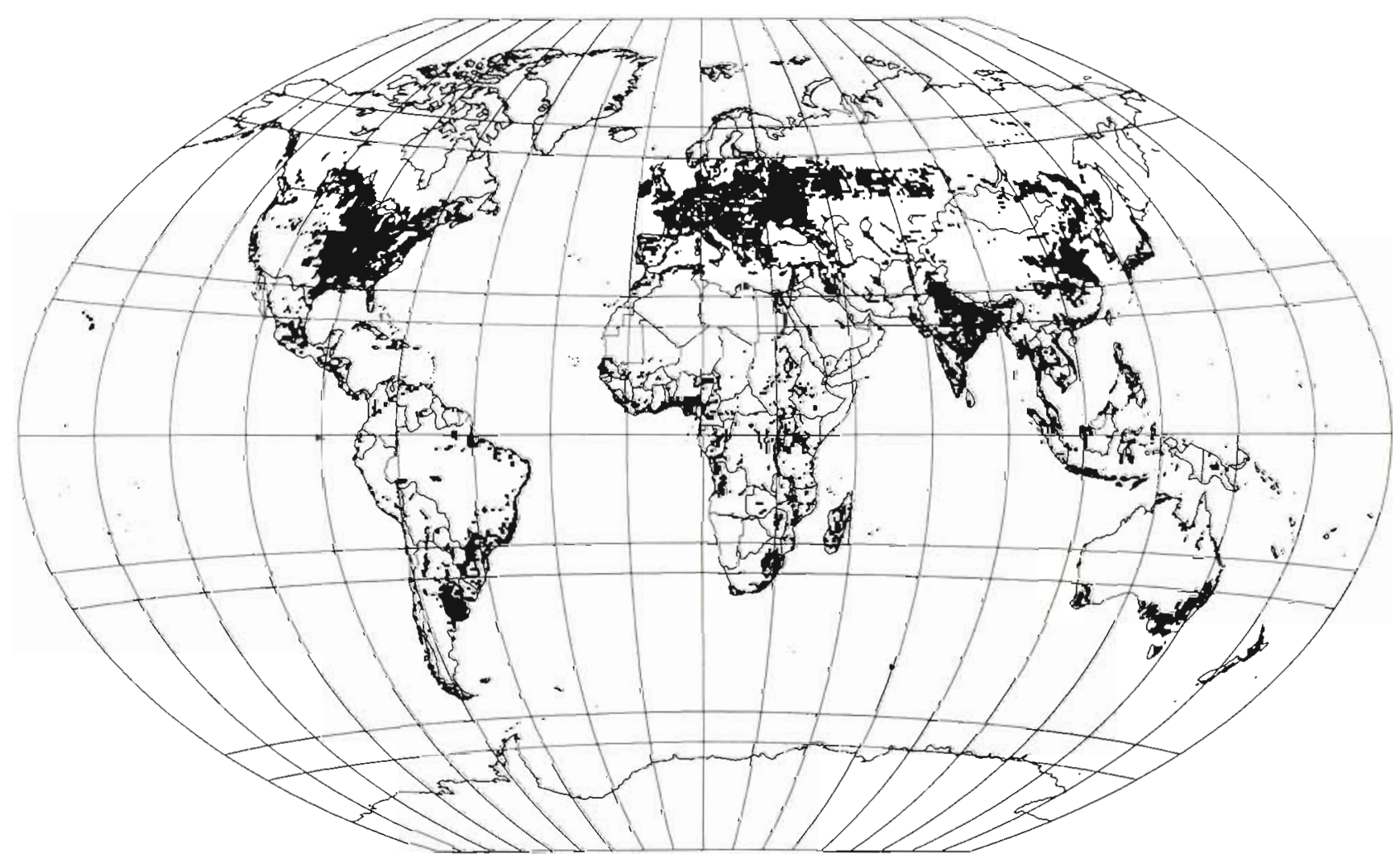

Fig 1. Global distribution of land designated as primarily cropland by Olson et al. (1983) 
region were much less successful because of the differences in effects on woody plants by the winter climate of coastal regions compared to that of continental interiors (Fig. 5 in Solomon et al. 1984). Apparently, agronomic crops are immune to the winter low temperature differences because their seeds are not stored in the soil in winter.

The dry boundaries of agricultural land coincide with a Priestley-Taylor ratio (Cramer \& Prentice 1988) of actual to potential evapotranspiration (AET:PET) of about 0.45 . That is, when the soil moisture available for evapotranspiration (AET) is less than half of the demand for moisture (PET) during the growing season, intensive agriculture cannot be carried out without irrigation. This value coincides closely with the relatively convoluted dryland boundaries of agriculture in temperate and subtropical areas (e.g. central North America, eastern Europe and western Asia).

In subtropical and tropical regions of greater moisture availability, cold growing seasons are unknown and most land would be classed as agricultural. Yet. clearly, many soil systems within tropical latitudes do not support intensive agriculture (Fig. 1). This is evident even under definitions of agricultural land which include much less intensively farmed areas, as do the several classes of agriculture intensity illustrated by Matthews (1983). Low human population densities and reliance on subsistence farming techniques may account for much of the discrepancy. However, lateritic soils with little organic matter and low nutrient concentrations (e.g. Zinke et al. 1984) may also play a significant role. These soil properties are characteristic of regions in which large amounts of rainfall and warm year-round temperatures promote high rates of nutrient uptake and rapid metabolism of soil organic matter by respiration among soil microorganisms.

Following this logic, we examined the global distribution of high Priestley-Taylor values (as indicators of generous moisture supplies throughout the year) and of warm winter temperatures (as indicators of warm conditions throughout the year). We found that much of the geography of tropical and subtropical farming in the agriculture maps of both Olson et al. (Fig. 1) and Matthews (1983) is retained by eliminating as farmed land those areas in which 2 conditions coincide: the coldest monthly temperatures are above $15.5{ }^{\circ} \mathrm{C}$ when the Priestley-Taylor ratio is above 0.70 . These are essentially the moist and wet tropical forest areas which our atlases illustrate to be carrying as high a human population density as adjacent, dryer or cooler, intensively farmed areas. In these areas, too much moisture becomes limiting due to its ability to leach nutrients, which in turn are rapidly made available from plant detritus by the constant presence of warmth and moisture.
The boundaries of 'agricultural land' which result from application of these climatic threshold values (Fig. 2) are a reasonable match to the geographic distributions of land uses mapped by Olson et al. (1983) which it was developed to mimic (Fig. 1). The agricultural land patterns of the temperate regions, in particular, are closely matched by the climatic envelope. Indeed, these defined and actual patterns compare much more favorably than do those pairs of wildland vegetation biomes defined by the Biome model and documented by Olson et al. (cf. Fig. 1a to d in Prentice et al. 1992a).

Certainly, the map of potential agricultural land is not entirely satisfactory. Most obviously, it contains a land area $\left(41.53 \times 10^{6} \mathrm{~km}^{2}\right)$ about $40 \%$ greater than the land use areas defined by Olson et al. $\left(25.12 \times 10^{6} \mathrm{~km}^{2}\right)$, and $23 \%$ greater than the range of agricultural areas defined by Matthews $\left(32.05 \times 10^{6} \mathrm{~km}^{2}\right)$. The Olson et al. data furthermore contained irrigated agriculture amounting to about $16 \%$ of agricultural land. Our objective was to define the area in which climate is not limiting to the practice of nonirrigated agriculture, i.e. the area of potential agriculture. However, the potential rarely is matched by a realized area of agriculture. Within the climatic envelope we defined, agriculture is additionally limited by the amount of land humans actually choose to use versus those left to natural vegetation, by the level of technology employed to develop farmed lands, by the depth and fertility of soils, by drainage and landforms, and by other non-climatic variables.

We therefore calculated agricultural area as (1) sparse agriculture, that is, $50.5 \%$ of the area within the climate envelope, matching the Olson et al. agriculture density. This calculation assumes current agricultural intensity will be unchanged in the future. We also calculated (2) dense agriculture, that is, the total area within the climatic envelope. This area represents all land which climate would allow to be farmed, as though other considerations do not reduce the maximum potential area. Because increasing population densities are likely to enhance the intensity of agriculture in the future, we suggest that a realistic value of future agricultural land lies between the sparse and dense agriculture values.

Model exercise methods. The Biome model with and without the agricultural climate envelope was used to project a current distribution of biomes based on the 62483 cells in the IIASA half degree latitude and longitude gridded climate data set (Leemans \& Cramer 1991). The climate data used for each cell include longterm monthly means of temperature, rainfall and percent sunshine interpolated from a global network of meteorological stations From these values, estimates of summer and winter temperature, annual growing 


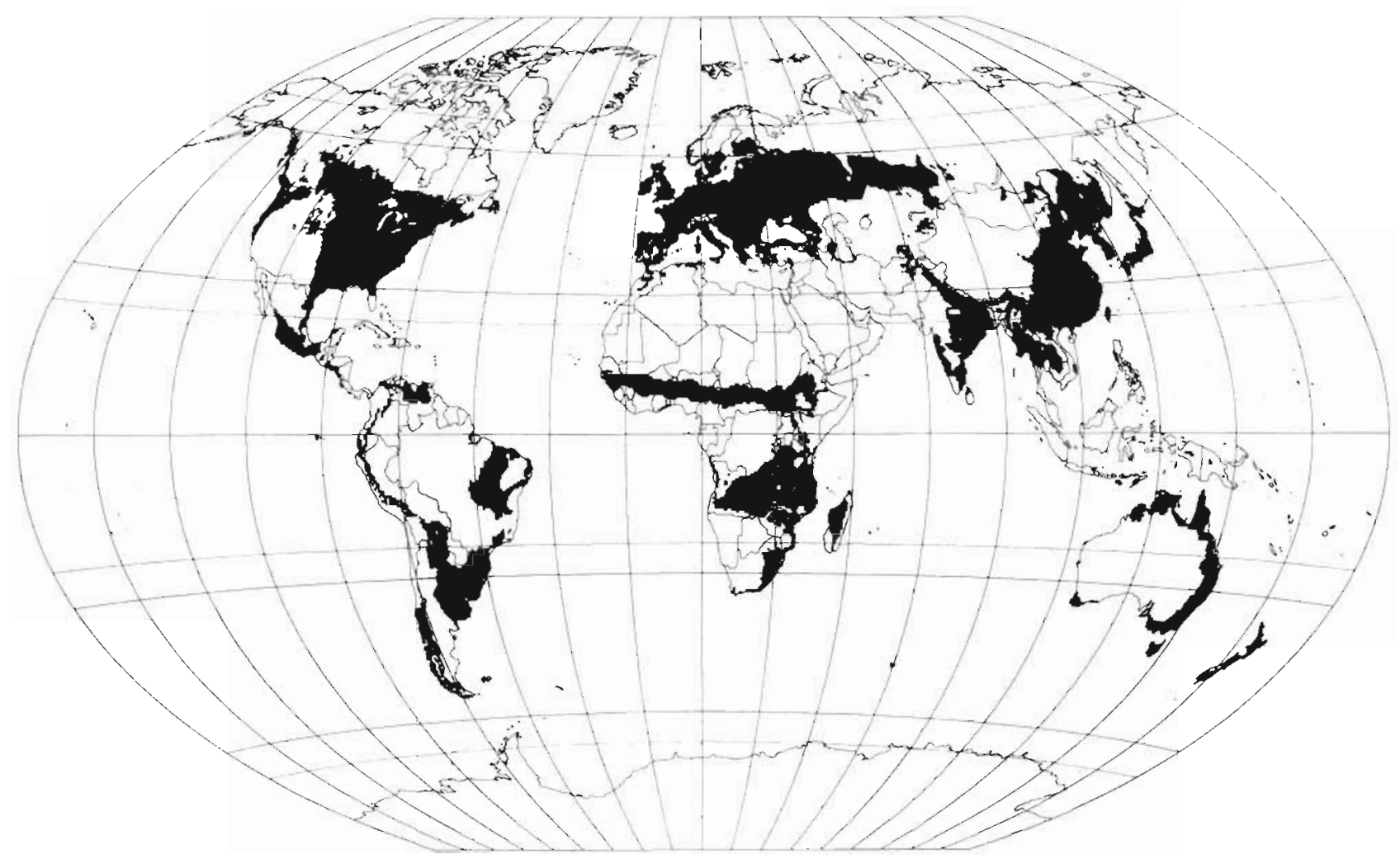

Fig. 2. Global distribution of land designated as potential agricultural land, based on the climate envelope formed by (1) growing degree-day values $\left({ }^{\circ} \mathrm{C}\right.$ ) greater than 2000 and (2) Priestley-Taylor ratio (Cramer \& Prentice 1988) greater than 0.45 , but excluding areas where (3) January temperature is greater than $15.5^{\circ} \mathrm{C}$ and Priestley-Taylor ratio is greater than 0.70

degree days, and potential and actual evapotranspiration were generated, based on the methods of Prentice et al. (1992a). Soils data consisted of soil water storage capacity, derived from soil texture classes of Zobler (1986) as described by Prentice et al. (1992a).

The Biome model also projected the distribution of biomes under the climate projected by atmospheric general circulation models (GCMs) from a doubling of greenhouse gas concentrations. We followed the procedures developed by Leemans (1989). Smith et al. (1992), Prentice \& Sykes (1993), and others, by applying gridded climate differences (anomalies) between GCM runs at $1 \times \mathrm{CO}_{2}$ and at $2 \times \mathrm{CO}_{2}$ to the observed gridded climate variables.

The Biome model was run, based on differences between current $\left(1 \times \mathrm{CO}_{2}\right)$ and $2 \times \mathrm{CO}_{2}$ climates simulated by 4 separate GCMs of the atmosphere: the United Kingdom Meteorological Office model (UKMO) of Mitchell (1983); the Princeton Geophysical Fluid Dynamics Laboratory model (GFDL) of Manabe \& Wetherald (1987); the Goddard Institute for Space Studies model (GISS) of Hansen et al. (1988); and the Oregon State University model (OSU) of Schlesinger \& Zhao (1989). These are listed in order of decreasing impact of their $2 \times \mathrm{CO}_{2}$ minus $1 \times \mathrm{CO}_{2}$ differences. The UKMO and GFDL scenarios ('extreme scenarios'), 2 closely related models, project large climate changes overall and the GISS and OSU scenarios ('moderate scenarios') predict more moderate changes. All 4 scenarios differ significantly in the details of the geographic distribution of climate changes they predict, particularly for precipitation.

Each of the climate scenarios was originally developed to emphasize one or another set of processes, primarily, dynamic processes in the upper atmosphere (Schlesinger \& Mitchell 1985). Hence, their behavior with respect to reality at ground level differs, but not in a manner which permits their simple characterization as, for example, most appropriate or least appropriate for our purposes. The climate envelope would be most useful when used with GCMs which reproduce observed patterns of summer temperatures and precipitation at high and mid latitudes, and of winter temperatures and annual precipitation at low latitudes.

Boer et al. (1991) tabled comparisons between 3 of the GCMs (GISS was not included). These data indicated that the GFDL model was best at reproducing 
summer temperatures at high and mid latitude, followed closely by the OSU GCM. GFDL was also strongest in reproducing summer precipitation in mid and low latitudes, while either UKMO or OSU did best in simulating winter temperatures at low latitude. Analyses by Gates et al. (1990, Table 4.2) which included all 4 models covered only 5 selected mid- and low-latitude regions and no high latitudes. Those data indicate that GISS, among the 4 models, produced the best simulation of observed mid-latitude summer temperature values, and of observed mid-latitude summer precipitation values. Kalkstein (1991) reported and illustrated linear transects comparing modeled and observed climate for all 4 GCMs. The GISS model performed best for temperature, OSU was best at reproducing precipitation patterns, but the GFDL model was second best in both categories, and hence, could be considered the best model at replicating the complete suite of climate variables.

Carbon content of above-ground biomass and below-ground soils was estimated for each biome and for agricultural land in each model run. The range of biomass C values calculated by Olson et al. (1983) and of soil C values tabulated by Zinke et al. (1984) linked biomes with $C$ storage values (Table 1). Agricultural land, which replaced biomes after their distribution was projected, was assigned an above-ground biomass $C$ content of zero. In keeping with the estimates of Mann (1986), soil retained $80 \%$ of the carbon assigned to soil in each biome.

\section{RESULTS}

The analysis first considers the shifts of land areas suitable for intensive agriculture, then examines the implications of the changes for future $\mathrm{C}$ storage in the terrestrial biosphere (Tables $2 \& 3$ and Figs. 3 to 6 ).

\section{Changes in area}

The total area of agriculture increased with all climate scenarios, from about $18 \%$ under the OSU climate to about $38 \%$ under the UKMO climate (Table 2 ). Inspection of the gains and losses producing the individual areal changes reveals important differences among the 4 cases. The moderate climate scenarios (OSU, GISS) produce notably less gain in agricultural area than do the severe scenarios (UKMO, GFDL), but

Table 1. Carbon densities of above-ground biomass and below-ground soils by biome type $\left(\mathrm{kg} \mathrm{m}^{-2}\right.$ of land surface)

\begin{tabular}{|c|c|c|c|c|c|c|}
\hline \multirow[t]{2}{*}{ Biomes } & \multicolumn{3}{|c|}{ Above-ground mass ${ }^{a}$} & \multicolumn{3}{|c|}{ Below-ground soils ${ }^{b}$} \\
\hline & Low & Medium & High & Low & Medium & High \\
\hline \multicolumn{7}{|l|}{ Tropical forests } \\
\hline Tropical rain forest & 10.0 & 14.0 & 17.0 & 9.5 & 10.4 & 11.3 \\
\hline Tropical seasonal forest & 10.0 & 14.0 & 17.0 & 9.5 & 10.4 & 11.3 \\
\hline Tropical dry forest & 3.2 & 4.6 & 6.6 & 6.3 & 7.3 & 8.3 \\
\hline Xerophytic woods/shrubs & 2.0 & 4.1 & 7.3 & 6.7 & 7.3 & 7.9 \\
\hline \multicolumn{7}{|l|}{ Temperate forests } \\
\hline Broadleaf evergreen forest & 6.0 & 10.0 & 14.0 & 12.3 & 13.3 & 14.2 \\
\hline Temperate deciduous forest & 8.0 & 10.0 & 14.0 & 12.7 & 15.2 & 17.7 \\
\hline Cool mixed forest & 6.0 & 10.0 & 14.0 & 10.5 & 13.0 & 15.5 \\
\hline Cool evergreen forest & 12.0 & 16.8 & 20.0 & 13.8 & 14.7 & 15.6 \\
\hline \multicolumn{7}{|l|}{ Boreal forests } \\
\hline Cold deciduous forest & 2.0 & 5.0 & 8.0 & 11.1 & 12.9 & 24.7 \\
\hline Taiga & 4.4 & 8.7 & 11.7 & 12.7 & 16.6 & 20.5 \\
\hline Cold mixed forest & 1.0 & 2.0 & 5.0 & 10.0 & 16.6 & 23.3 \\
\hline \multicolumn{7}{|l|}{ Grasslands } \\
\hline Warm grasslands & 0.8 & 1.3 & 2.5 & 7.2 & 8.7 & 10.2 \\
\hline Cool grasslands & 0.5 & 1.0 & 2.4 & 11.6 & 12.3 & 13.0 \\
\hline Tundra & 0.5 & 0.8 & 1.3 & 15.7 & 18.2 & 20.7 \\
\hline \multicolumn{7}{|l|}{ Deserts } \\
\hline Hot desert & 0.1 & 0.3 & 0.7 & 2.5 & 3.0 & 3.5 \\
\hline Semidesert & 0.3 & 0.6 & 1.0 & 4.1 & 6.2 & 8.3 \\
\hline Ice/polar desert & 0.0 & 0.0 & 0.0 & 0.0 & 0.0 & 0.0 \\
\hline $\begin{array}{l}\text { da From Olson et al. (1983) } \\
{ }^{b} \text { From Zinke et al. (1984) }\end{array}$ & & & & & & \\
\hline
\end{tabular}


Table 2. Change in biome areas with different climates and land use scenarios in $10^{3} \mathrm{~km}^{2}$

\begin{tabular}{|c|c|c|c|c|c|c|}
\hline \multirow[t]{2}{*}{ Biome name } & \multicolumn{2}{|c|}{ Current area of: } & \multicolumn{4}{|c|}{ Change by: } \\
\hline & $\begin{array}{c}\text { Natural } \\
\text { vegetation }\end{array}$ & Agriculture & OSU & GISS & GFDL & UKMO \\
\hline \multicolumn{7}{|l|}{ Tropical forests } \\
\hline Tropical rain forest & 8455 & 9 & 5 & 6 & -2 & 2 \\
\hline Tropical seasonal forest & 7960 & 10 & 7 & -1 & 12 & -2 \\
\hline Tropical dry forest & 10921 & 6130 & 641 & 1020 & 770 & 1651 \\
\hline Xerophytic woods/shrubs & 9479 & 1343 & -266 & -293 & -207 & -189 \\
\hline \multicolumn{7}{|l|}{ Temperate forests } \\
\hline Broadleaf evergreen forest & 2943 & 2943 & 561 & 719 & 1170 & 1168 \\
\hline Temperate deciduous forest & 2982 & 2982 & 611 & 612 & 647 & 659 \\
\hline Cool mixed forest & 2572 & 2572 & 577 & 2357 & 2308 & 2655 \\
\hline Cool evergreen forest & 2097 & 1090 & 343 & 187 & 567 & 676 \\
\hline \multicolumn{7}{|l|}{ Boreal vegetation } \\
\hline Cold mixed forest & 338 & 306 & -88 & -187 & -83 & -76 \\
\hline Taiga & 12910 & 616 & 913 & 439 & 1377 & 1294 \\
\hline Cold deciduous forest & 3455 & 242 & 117 & -84 & -83 & -82 \\
\hline Tundra & 8769 & 3 & -3 & -3 & -3 & -3 \\
\hline \multicolumn{7}{|l|}{ Grasslands and deserts } \\
\hline Hot desert & 19455 & 0 & 0 & 0 & 0 & 0 \\
\hline Warm grasslands & 10977 & 810 & 1016 & 823 & 1089 & 1091 \\
\hline Semidesert & 4995 & 0 & 0 & 0 & 0 & 0 \\
\hline Cool grasslands & 4203 & 1477 & -781 & -979 & -936 & -1050 \\
\hline Ice/polar desert & 2496 & 0 & 0 & 0 & 0 & 0 \\
\hline Total & 115007 & 20533 & 3653 & 4616 & 6626 & 7794 \\
\hline
\end{tabular}

surprisingly, the moderate scenarios lose more agricultural land than do the severe ones. Examination of the geographic patterns of agricultural land gain and loss (Figs. 3 to 6) indicates no systematic differences among the scenarios in land loss. The moderate scenarios project losses of agricultural land south of sub-Saharan Africa, and all 4 indicate large declines in the granaries of the Pampas in northeastern Argentina and, for GISS and UKMO, in adjacent Uruguay. OSU alone among the 4 produces large losses of marginal agricultural land in eastern Brazil (Caatinga) where today only cattle ranching occurs, and in Thailand in areas which support intensive subsistence farming, but little largescale rice (Oryza sp.) production (Fig. 3). The UKMO scenario is also singular in producing losses of marginal non-irrigated agricultural land in the grainproducing states of Colorado, Wyoming and Montana, USA, and adjacent Saskatchewan, Canada (Fig. 6).

The regions which gain agricultural land are considerably easier to recognize. These are the southern and central boreal forest regions of Canada, Europe and Asia under the moderate scenarios (Figs. 3 \& 4), and about twice as much area, i.e. almost the entire circumpolar boreal forest region of today, under the severe scenarios (Figs. $5 \& 6$ ). Both GFDL and UKMO scenarios project potential agricultural land covering all of Scandinavia and most of Europe to the Arctic Circle, Siberia west of the Ural Mountains, including most of Yakutia, the majority of Alaska, and most of the Ungava Peninsula of Labrador. Elsewhere, the 2 moderate scenarios project an approximate doubling of agricultural land in northern Australia, while neither severe scenario suggests any change there.

One unanswered question involves effects on current vegetation of future agriculture. What if slow plant migration rates precluded any change in the geography of current biomes by the time a climate induced by $\mathrm{CO}_{2}$ doubling appears? What if, in addition, agriculture responded to that climate change almost instantaneously as many agronomists believe it can? The major changes in areas occupied by agriculture under these circumstances include agriculture increases from about $5 \%$ to between $26 \%$ (OSU) and $42 \%$ (GFDL) of the circumpolar taiga area, from $35 \%$ to $51 \%$ (all scenarios) of cool conifer forest (the southern Taiga of Europe and Siberia, and southern boreal forest of eastern North America), and from $7 \%$ to between 20\% (GISS) and 32\% (UKMO) of the cool deciduous forest found primarily in central Siberia. Agriculture declines from $50 \%$ to between $30 \%$ (UKMO) and $38 \%$ (GFDL) in areas now occupied by broadleaved evergreen forest. 


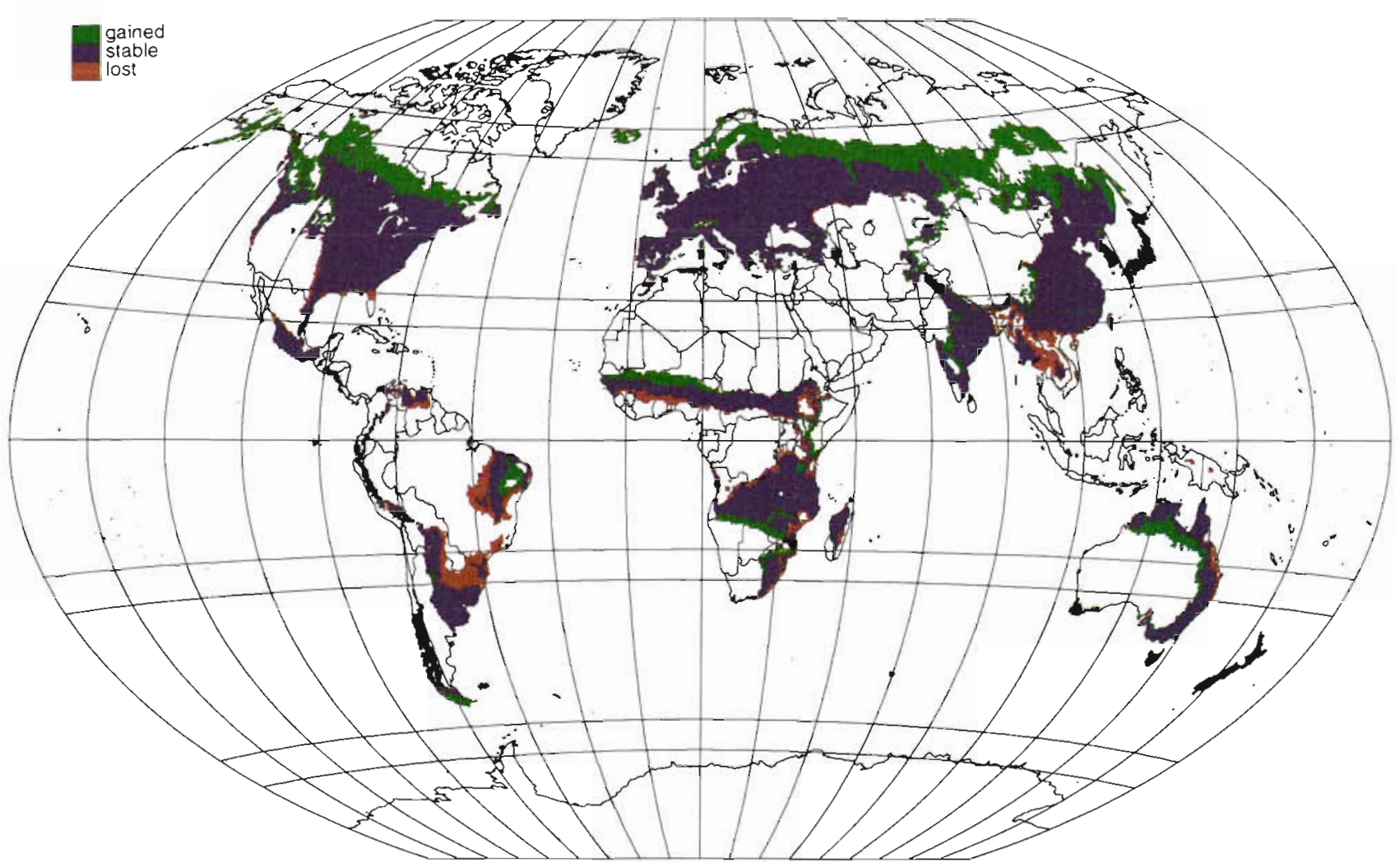

Fig. 3. Global distribution of potential agricultural land today, new potential agricultural land gained, and that lost under climate resulting from a doubling of atmospheric $\mathrm{CO}_{2}$, based on the OSU climate scenario of Schlesinger \& Zhao (1989)

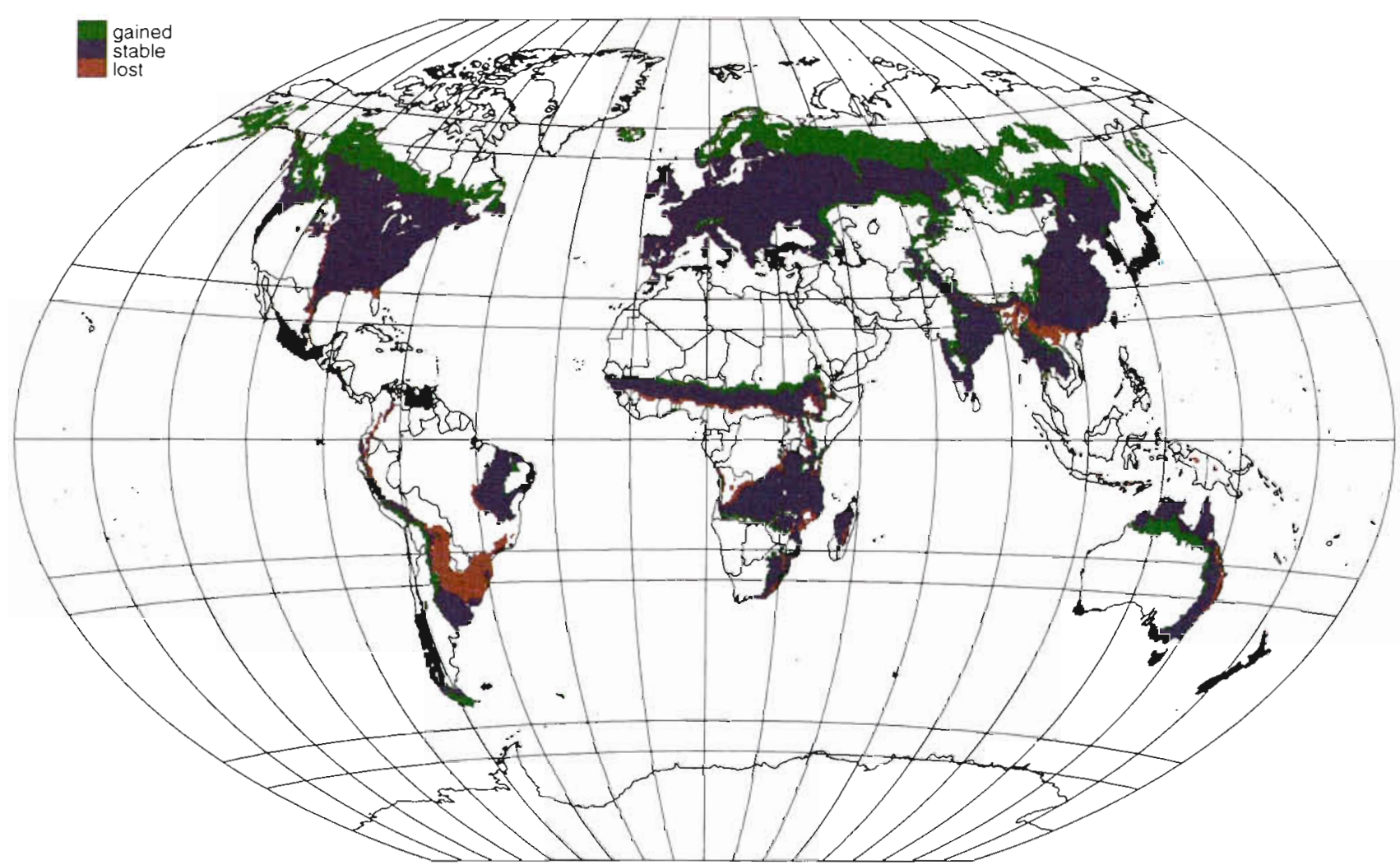

Fig. 4. Global distribution of potential agricultural land today, new potential agricultural land gained, and that lost under climate resulting from a doubling of atmospheric $\mathrm{CO}_{2}$, based on the GISS climate scenario of Hansen et al. (1988) 


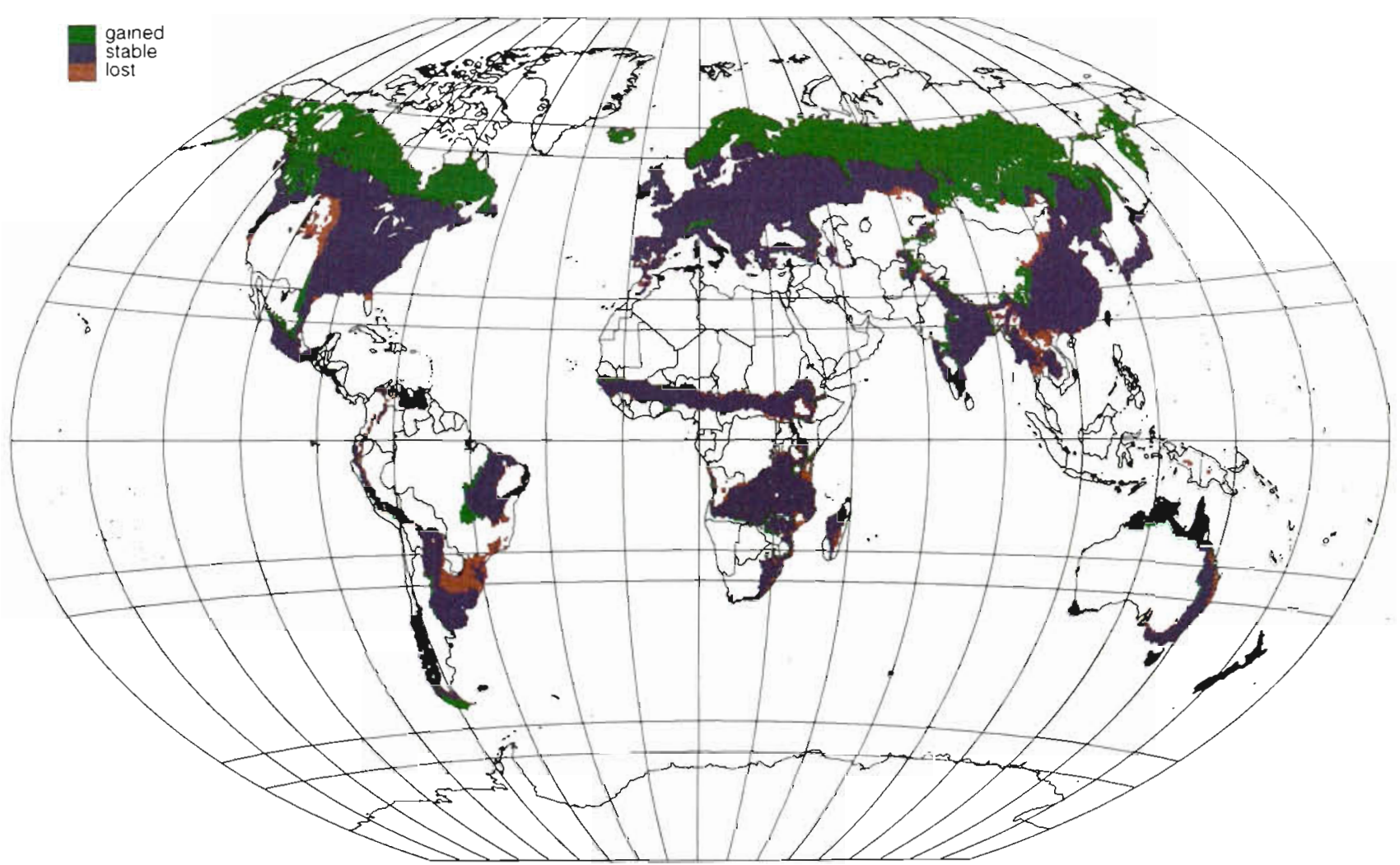

Fig. 5. Global distribution of potential agricultural land today, new potential agricultural land gained, and that lost under climate resulting from a doubling of atmospheric $\mathrm{CO}_{2}$, based on the GFDL climate scenario of Manabe \& Wetherald (1987)

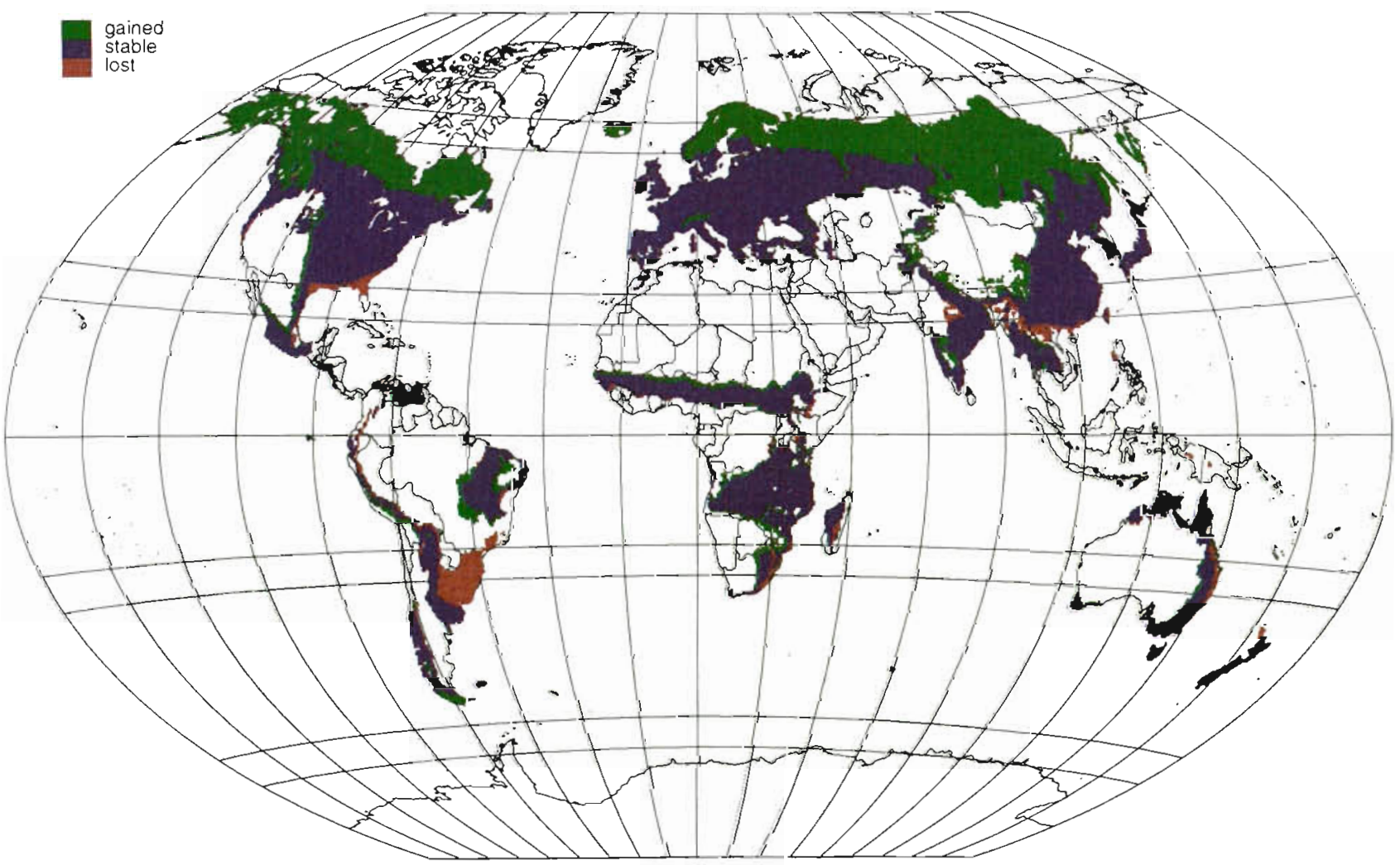

Fig. 6. Global distribution of potential agricultural land today, new potential agricultural land gained, and that lost under climate resulting from a doubling of atmospheric $\mathrm{CO}_{2}$, based on the UKMO climate scenario of Mitchell (1983) 
Table 3. Carbon (Pg) stored above- and below-ground under differing climate and land use scenarios, and differences with storage under normal climate conditions

\begin{tabular}{|c|c|c|c|c|c|c|c|c|}
\hline & \multicolumn{3}{|c|}{ Above-ground $\mathrm{C}$} & \multicolumn{3}{|c|}{ Below-ground C } & \multirow{2}{*}{$\begin{array}{c}\text { Total } \\
\text { (Med.+Med.) }\end{array}$} & \multirow[t]{2}{*}{ Difference } \\
\hline & Low & Medium & High & Low & Medium & High & & \\
\hline \multicolumn{9}{|l|}{ Under normal climate } \\
\hline Without agriculture & 483 & 754 & 1041 & 1127 & 1367 & 1606 & 2121 & \\
\hline With sparse agriculture & 383 & 604 & 829 & 1119 & 1313 & 1547 & 1916 & \\
\hline With dense agriculture & 286 & 457 & 622 & 1046 & 1273 & 1498 & 1730 & \\
\hline \multicolumn{9}{|l|}{ Under UKMO climate } \\
\hline Without agriculture & 556 & 852 & 1170 & 1111 & 1310 & 1509 & 2162 & 41 \\
\hline With sparse agriculture & 412 & 631 & 862 & 1064 & 1243 & 1433 & 1874 & -42 \\
\hline With dense agriculture & 264 & 405 & 547 & 998 & 1177 & 1356 & 1582 & -148 \\
\hline \multicolumn{9}{|l|}{ Under GFDL climate } \\
\hline Without agriculture & 545 & 834 & 1146 & 1106 & 1303 & 1499 & 2137 & 16 \\
\hline With sparse agriculture & 406 & 621 & 850 & 1060 & 1238 & 1426 & 1859 & -57 \\
\hline With dense agriculture & 264 & 404 & 547 & 997 & 1174 & 1351 & 1578 & -152 \\
\hline \multicolumn{9}{|l|}{ Under GISS climate } \\
\hline Without agriculture & 571 & 875 & 1194 & 1142 & 1349 & 1555 & 2224 & 103 \\
\hline With sparse agriculture & 444 & 682 & 923 & 1104 & 1290 & 1489 & 1972 & 56 \\
\hline With dense agriculture & 314 & 484 & 646 & 1043 & 1232 & 1421 & 1716 & -14 \\
\hline \multicolumn{9}{|l|}{ Under OSU climate } \\
\hline Without agriculture & 554 & 849 & 1157 & 1130 & 1348 & 1566 & 2197 & 76 \\
\hline With sparse agriculture & 435 & 668 & 904 & 1103 & 1291 & 1502 & 1959 & 43 \\
\hline With dense agriculture & 312 & 483 & 645 & 1034 & 1235 & 1436 & 1718 & -12 \\
\hline
\end{tabular}

\section{Changes in $\mathrm{C}$ stocks}

The range of potential terrestrial $C$ pools (Table 3 ) is estimated at 3 levels (low, medium, high) and separated as above-ground biomass and below-ground soil carbon, all calculated in Petagrams ( $\mathrm{Pg} ; 10^{15} \mathrm{~g}$ ). These represent the areas of each biome, multiplied by the $C$ density values for each biome from Table 1. Low and high values were originally provided to characterize the uncertainties surrounding the median values (Olson et al. 1983, Zinke et al. 1984) and are provided here for comparison with data of other investigators (e.g. Prentice \& Sykes 1993, Prentice et al. 1993b) although we analyzed only data on the medium C stocks. Values are calculated for the $\mathrm{C}$ stored in a terrestrial biosphere with no agriculture ('Without agriculture', Table 3), in a biosphere in which a lesser percentage of 'potential' agricultural land is actually used (i.e. $50.5 \%$; 'With sparse agriculture'), and in which all land capable of intense agriculture is so used ('With dense agriculture').

The $C$ stocks under current climate estimated by the Biome model with sparse agriculture, and those estimated from the literature, are quite similar. Olson et al. (1983) provide above-ground estimates for low, medium and high biomass of 360,558 , and $807 \mathrm{Pg} \mathrm{C}$, compared to our low, medium and high values of 383 , 604, and $829 \mathrm{Pg}$ respectively. For a world without agriculture, our medium biomass estimate of $754 \mathrm{Pg} \mathrm{C}$ compares reasonably well with that by Whittaker \&
Likens (1975) of $827 \mathrm{Pg}$, and by Matthews (1983) of 840 Pg. Recent evidence (e.g. Botkin \& Simpson 1990, 1993, Apps \& Kurz 1993) suggests that much lower above-ground $\mathrm{C}$ stocks exist in boreal and temperate forest regions than suspected by Olson et al., suggesting that the low values rather than the medium ones of Olson et al. could be more accurate estimators for global terrestrial biomass stocks.

We have no measurement of global soil $\mathrm{C}$ disturbed by agriculture. However, for undisturbed soils, Zinke et al. (1984) estimated soil $\mathrm{C}$ at $1400 \mathrm{Pg}$, and Schlesinger (1977) estimated the value at $1456 \mathrm{Pg}$, compared to our medium soil $\mathrm{C}$ estimate of $1366 \mathrm{Pg}$ (Table 3). Hence, we concluded that the Biome model with its additional agricultural climate envelope adequately reproduces the expected values of today's global carbon stocks.

The difference between medium $C$ stocks under modern climate and those under a doubled concentration of atmospheric $\mathrm{CO}_{2}$ is significant. With dense agriculture included in the calculation, $\mathrm{C}$ stocks decline in soils and in the terrestrial biosphere as a whole in all 4 cases (Table 3 ). However, the $\mathrm{C}$ storage estimates form a dichotomy between the moderate (GISS, OSU) and the extreme (UKMO, GFDL) scenarios. The decline in biospheric $\mathrm{C}$ storage in the case of the moderate scenarios is negligible (11 to $13 \mathrm{Pg}$ in a budget of $1700 \mathrm{Pg}$ ) but is clearly important in the extreme scenarios (147 to $151 \mathrm{Pg}$ ). Compared with total $\mathrm{C}$ losses, soil $\mathrm{C}$ losses are more similar for the 2 kinds of scenarios, ranging 
from 35 and $39 \mathrm{Pg}$ (moderate scenarios) to 95 and $98 \mathrm{Pg}$ (extreme scenarios). Patterns apparent in Table 2 suggest that the loss of $\mathrm{C}$ in soils occurs primarily because of the decline in area covered by high-carbon boreal and tundra soils, and secondarily, in broadleaved evergreen forests.

The dichotomy continues with sparse agriculture. Although carbon declines in all soils, and increases in all vegetation, the moderate scenarios show a total increase of 43 to $56 \mathrm{Pg}$ while the extreme scenarios lose between 42 and $57 \mathrm{Pg}$ of total carbon. Above-ground biomass values alone are less variable, but retain the dichotomy between moderate and extreme scenarios (Table 3). The GISS and OSU scenarios gain about $70 \mathrm{Pg} \mathrm{C}$ each with sparse agriculture, and $27 \mathrm{Pg}$ each with dense agriculture, compared with current climate effects. The extreme scenarios gain little with sparse agriculture, and lose about $52 \mathrm{Pg}$ each with dense agriculture. The gains in $\mathrm{C}$ stocks under the moderate scenarios are registered in wildland rather than in agricultural lands, primarily by large gains in tropical seasonal and rain forests, while land under these tropical biomes in the extreme scenarios increased little (Prentice \& Sykes 1993).

The potential role of agriculture in shifting the terrestrial carbon balance can be estimated by comparing the terrestrial C stocks when agriculture is included, as we have done above, with such calculations in the absence of agriculture (Table 3), as has been the usual practice (e.g. Emanuel et al. 1985, Leemans 1989, Prentice \& Fung 1990, Smith et al. 1992, Neilson et al. 1993, Prentice \& Sykes 1993, Prentice et al. 1993b). In the case of no agriculture, the Biome model estimates of $C$ stocks project trends similar to those shown by others: above-ground biomass increases in all 4 cases, below-ground $\mathrm{C}$ decreases in all 4 cases, and total $\mathrm{C}$ increases slightly to moderately (16 to $104 \mathrm{Pg}$ in a budget of 2100 to $2200 \mathrm{Pg}$ ) in all 4 cases. The dichotomy between moderate and extreme climate scenarios disappears in the no-agriculture estimates of aboveground C stocks (95 and $120 \mathrm{Pg}$ for OSU and GISS respectively; 80 and $98 \mathrm{Pg}$ for GFDL and UKMO respectively), although it is retained in soil $\mathrm{C}(-18 \mathrm{Pg}$ each for GISS and OSU; -57 and $-64 \mathrm{Pg}$ for UKMO and GFDL respectively)

Beyond the obvious differences in which all scenarios generate carbon storage gains (no agriculture), slight gains to moderate losses (sparse agriculture), and moderate to large losses (dense agriculture), one may wish to consider how much difference there is among the dense, sparse, and no land use conditions. The disparity between Biome $C$ estimates of warming impacts without agriculture and with sparse agriculture ranges between $33 \mathrm{Pg}$ (OSU scenario) and $83 \mathrm{Pg}$ (UKMO scenario). The disparity between Biome esti- mates of warming impacts without agriculture and those with dense agriculture ranges between $88 \mathrm{Pg}$ (OSU scenario) and $188 \mathrm{Pg}$ (UKMO scenario). In the perspective of reaching a climate associated with doubling of greenhouse gases in 50 to 100 yr (e.g. IPCC 1992), these results imply a terrestrial C source of about 0.3 to $1.7 \mathrm{Pg} \mathrm{yr}^{-1}$ with sparse agriculture, and 0.9 to $3.8 \mathrm{Pg} \mathrm{yr}^{-1}$ with dense agriculture, which is not accounted for in model runs that exclude impacts of agriculture on the global carbon cycle. Notably, the modeled climatic impact of the same warming, acting on equilibrium vegetation without agriculture (the 16 to $104 \mathrm{Pg}$ cited above), is about the same but opposite in sign to the sparse agriculture carbon flux, generating a global C sink of 0.2 to $2.1 \mathrm{Pg} \mathrm{yr}^{-1}$.

\section{DISCUSSION}

The implications of the foregoing exercise are of most concern in 2 areas. First, the globe's carrying capacity for human populations is likely to depend largely on the amount of arable land in a future warmed and crowded world; this amount was projected by mapped distributions of climate-constrained farmlands today and in the future. Second, the earth's future role has been ambiguous as either a net source or a net sink for $\mathrm{C}$ in amplifying or ameliorating, respectively, the expected climatic warming. This role depends, in turn, on the changing carbon storage capacity of biomes in the terrestrial biosphere; these storage capacities were calculated, for the first time including the potential role of agriculture, from the mapped present and future distribution of biomes and farmed lands, multiplied by the estimated above- and below-ground $\mathrm{C}$ storage of each.

When we consider the potential distribution of agriculture projected by the climate scenarios, the importance of the scenarios themselves is immediately obvious. The scanty evidence in the literature suggests that the GFDL, and possibly GISS, scenario is likely to be more accurate for the purposes of this assessment (see 'Model exercise methods', above). Under this assumption, the expectation for future areas of potentially intensive agriculture is not bright. An increase in total agricultural land area between 22 and $32 \%$ is projected for the time required to reach the climate of doubled atmospheric $\mathrm{CO}_{2}$, some 50 to $100 \mathrm{yr}$ in the future. At current doubling rates of human populations (e.g. Keyfitz 1989) of 35 to $40 \mathrm{yr}$, the population to be supported by one-fourth to one-third more agricultural land would be 1 to $2 \frac{1}{2}$ times greater than it is today. Even under very conservative assumptions, Easterling et al. (1989) estimate increases of demand for food and fiber of 60 to $80 \%$ by the time $\mathrm{CO}_{2}$ is expected to 
double, and they suggest a more likely value would be 2 to $2 \frac{1}{2}$ times greater than the demand of the mid1980s. Notably, the gains in agriculture are almost entirely in the developed countries of high latitudes, and the losses, in the less developed countries of the lower latitudes.

Perhaps more significant to human needs for food are the greater losses of already farmed lands calculated by the moderate scenarios compared to the extreme scenarios. These losses occurred almost exclusively in the driest of arable lands. Although developed countries may offset some of the losses with irrigation, the rapidly increasing populations in less developed countries produce great pressure on land resources, and hence, are most likely to undergo desertification in these peripheral areas. Even the extreme future scenarios increase only 32 to $38 \%$ in new arable land, and their concomitant loss of currently arable land provides little ground for optimism concerning future food supplies.

The future role of agriculture in the response to climate change by the terrestrial $\mathrm{C}$ cycle, calculated in the foregoing analysis, appears to be at least as important as the role of the unmanaged biosphere alone. The difference between a global $\mathrm{C}$ cycle in which agriculture has no effect on responses to climate change and one in which agriculture acts to reduce $C$ stocks by at least 33 to $83 \mathrm{Pg}$ is significant. Assuming that climate change produced by a doubling of greenhouse gases occurs in $100 \mathrm{yr}$ (a conservative assumption according to IPCC 1990), the 0.3 to $0.8 \mathrm{Pg} \mathrm{yr}^{-1}$ contributed to the atmosphere by agriculture constitutes 5 to $10 \%$ of current annual carbon emissions from fossil fuels (e.g. IPCC 1992).

The analyses we present above appear to be conservative estimates of coupled climate and agricultural impacts on the carbon stocks of the terrestrial biosphere. We do not include the transient response of vegetation and of $C$ in soils, which are likely to generate a large source of atmospheric C from stressinduced forest dieback during the next century or so (e.g. Solomon 1986, Schlesinger 1990, Solomon \& Leemans 1990, King \& Neilson 1992, Prentice et al. 1993a, Smith \& Shugart 1993). In addition, we do not attempt to calculate decremental effects on biomass and soil $\mathrm{C}$ caused by irrigated agriculture or by increasing technological means (equipment, fertilizers, plant breeding) of making currently unusable land arable, a process likely to increase in importance with rapidly growing human populations.

On the other hand, we did not consider other processes suspected of increasing $\mathrm{C}$ storage in the terrestrial biosphere, i.e. by $\mathrm{CO}_{2}$ fertilization of unmanaged vegetation (e.g. Strain \& Cure 1985, Koerner 1993) and by growth of early successional forests which may constitute a much larger proportion of the global forest area than was previously thought (Brown et al. 1992). In a now controversial paper, Tans et al. (1990) concluded that the terrestrial biosphere must be taking up 2 to $3.4 \mathrm{Pg}$ of $\mathrm{C}$ annually, assuming the global ocean to be a sink for at most $1 \mathrm{Pg} \mathrm{C} \mathrm{yr}^{-1}$. Subsequent measurements of aceanic $C$ fluxes (Quay et al. 1992) imply an oceanic $C$ sink of 2 Pg, still leaving 1 to $2.4 \mathrm{Pg} \mathrm{C}$ for the terrestrial biosphere to absorb.

If the terrestrial biosphere is taking up $C$ as deduced by oceanographers, that is, if the implied causative processes of $\mathrm{CO}_{2}$ fertilization and early forest succession are operating, the $\mathrm{C}$ sequestration rate is likely to decline sharply in the future. With warming, high Cdensity forests and peatlands of temperate and high latitudes (hypothesized by e.g. Tans et al. 1990 to be acting at present as carbon sinks) are likely to be replaced with croplands in which no standing $C$ stocks exist above ground, and reduced carbon densities dominate soils. Additional quantities of stored $\mathrm{C}$ are likely to be released when early successional forests over the globe also are replaced by agriculture and as agriculture occupies land which otherwise would be devoted to early forest succession. Finally, any enhancement of $\mathrm{C}$ fixation by increasing atmospheric $\mathrm{CO}_{2}$ concentrations should decrease because the $\mathrm{C}$ fertilization measured in greenhouses appears to be an asymptotic process in which greater atmospheric concentrations of $\mathrm{CO}_{2}$ generate less and less enhancement of $C$ fixation (e.g. Regehr et al. 1975).

A set of related processes can be discerned from the foregoing discussion. First, the growing human population, which is responsible for increased use of fossil fuels, generation of greenhouse gases and the predicted climate warming, is likely to be even more important to global ecological functioning in the future through its conversion of land to support its rapidly expanding need for food. Second, as much as one-third of the increased agricultural land use in the future may be in the form of expansion into regions previously never capable of supporting agronomic crops, permitted only because of the parallel warming. Third, that land conversion will play a pivotal and previously unaddressed role in reducing the capability of the terrestrial biosphere to sequester atmospheric $C_{\text {, a }}$ development which will enhance warming

Acknowledgements. The authors greatly appreciate many discussions of this work with, and the use of cartographic software written by, Rik Leemans. The manuscript was carefully reviewed by Ronald Neilson and an anonymous reviewer. The work was supported by the Potsdam Institute for Climate Change Impacts Research, Potsdam, Germany, and the U.S. EPA, Corvallis, Oregon, through Cooperative Agreement CR 817453-01-0 with Michigan Technological University. 


\section{LITERATURE CITED}

Apps, M. J., Kurz, W. A. (1993). Contribution of northern forests to the global carbon cycle: Canada as a case study. Wat. Soil Air Pollut. (in press)

Boer, G. J., Arpe, K., Blackburn, M., DeQue, M., Gates, W. L., Hart, T L., le Treut, H., Roeckner, E., Sheinin, D. A., Simonds, I., Smith, R. N. B., Tokioka, T., Wetherald, R. T., Williamson, D. (1991). An intercomparison of the climates simulated by 14 atmospheric general circulation models. WCRP-58, WMO/TD-425, World Meteorological Organization, Geneva

Botkin, D. B., Janak, J. F., Wallis, J. R. (1972). Some ecological consequences of a computer model of forest growth. $\mathrm{J}$. Ecol. 60: 849-873

Botkin, D. B., Simpson, L. G. (1990). Biomass of the North American boreal forest: a step toward accurate global measures. Biogeochemistry 9: 161-174

Botkin, D. B., Simpson, L. G. (1993). Forests store less carbon than generally believed: the need for a new asses:ment of carbon sequestering by forests. Wat. Soil Air Pollut. (in press)

Box, E. O. (1981). Macroclimate and plant form: an introduction to predictive modeling in phytogeography. Dr. W. Junk, The Hague

Brown, S., Lugo, A. E., Iverson, L. R. (1992). Processes and lands for sequestering carbon in the tropical forest landscape. Wat. Soil Air Pollut. 64: 139-155

Clark, W. C., Richards, J., Flint, E. (1986). Human transformations of the earth's vegetation cover: past and future impacts of agricultural development and climatic change. In: Rosenzweig, C., Dickenson, R. (eds.) Climate-vegetation interactions. Report OIES-2, UCAR (University Corporation for Atmospheric Research), Boulder, CO, p. 54-59

Cohen, S. B. (1973). Oxford world atlas. Oxford University Press, New York

Cook, E. R. Cole, J. (1991). On predicting the response of forests in eastern North America to future climatic change. Clim. Change 19: 271-282

Cramer, W. P., Leemans, R. (1993). Asenssing impacts of climate change on vegetation using climate classification systems. In: Solomon, A. M., Shugart, H. H. Jr (eds.) Vegetation dynamics and global change. Chapman and Hall, New York, p. 190-217

Cramer, W. P., Prentice, I. C. (1988). Simulation of regional soil moisture deficits on a European scale. Norsk geogr. Tidskr. 42: 149-151

Crosson, P. (1989). Climate change: problems of limits and policy responses. In: Rosenberg, N. J., Easterling, W. E. III, Crosson, P. R., Darmstadter, J (eds.) Greenhouse warming: abatement and adaptation. Resources for the Future, Washington, DC, p. 83-88

Davis, M. B., Zabinski, C. (1992). Changes in geographical range resulting from global warming: effects on biodiversity in forests. In: Peters, R. L., Lovejoy, T. E. (eds.) Global warming and biological diversity. Yale University Press, New Haven, CT, p. 297-308

Decker, W. L., Jones, V. K., Achutuni, R. (1988). The impact of climatic change from increased atmospheric carbon dioxide on American agriculture. TR-031, U.S. Dept of Energy, Washington, DC

Easterling, W. E. III, Parry, M. L., Crosson, P. R. (1989) Adapting future agriculture to changes in climate. In: Rosenberg, N. J., Easterling, W. E. III, Crosson, P R., Darmstadter, J. (eds.) Greenhouse warming: abatement and adaptation. Resources for the Future, Washington, DC, p. $91-104$
Emanuel, W. R., Shugart, H. H. Jr, Stevenson, M. P. (1985) Climatic change and the broad-scale distribution of terrestrial ecosystem complexes. Clim. Change 7: 29-43

FAO (U.N. Food and Agriculture Organization) (1986). 1985 FAO Production Yearbook, Vol. 39. FAO, Rome

Gates, W. L., Rowntree, P. R., Zeng, Q.-C. (1990). Valudation of climate models. In: Houghton, J. T., Jenkins, G. J., Ephraums, J. J. (eds.) Climate change: the IPCC scientific assessment. WMO/UNEP. Cambridge University Press, Cambridge, p. 93-130

Hansen, J. I., Fung, I. Y., Lacis, A., Rind, D., Russell, G., Lebedeff, S., Ruedy, R. (1988). Global climate changes as forecast by the GISS 3-D model. J. geophys. Res. 93: 9341-9364

Houghton, R. A., Woodwell, G. M. (1989). Global climatic change. Scient. Am. 260: 18-26

Hummel, J. R., Reck, R. A. (1979). A global surface albedo model. J. appl. Meteorol. 18: 239-253

IPCC (Intergovernmental Panel on Climate Change) (1990). Climate change: the IPCC scientific assessment. WMO/UNEP. Cambridge University Press, Cambridge

IPCC (Intergovernmental Panel on Climate Change) (1992). Climate change 1992: the supplementary report to the IPCC scientific assessment. WMO/UNEP. Cambridge University Press, Cambridge

Kalkstein, L. S. (1991). Global comparisons of selected GCM control runs and observed climate data. 21P-2002, Office of Policy, Planning and Evaluation, U.S. EPA, Washington, $\mathrm{DC}$

Keyfitz, N. (1989). The growing human population. Scient. Am. 261:70-77A

King, G. A., Neilson, R. P. (1992). The transient response of vegetation to climate change: a potential source of $\mathrm{CO}_{2}$ to the atmosphere. Wat. Air Soil Pollut. 64: 365-383

Koerner, C. (1993). $\mathrm{CO}_{2}$ fertilization: the great uncertainty in future vegetation development. In: Solomon, A. M. Shugart, H. H. Jr (eds.) Vegetation dynamics and global change. Chapman and Hall, New York, p. 53-70

Leemans, R. (1989). Possible changes in natural vegetation patterns due to a global warming. In: Hackl, A. (ed.) Der Treibhauseffekt: Das Problem - Mögliche Folgen Erforderliche Maßnahmen. Akadamie für Umwelt und Energie, Laxenburg, Austria, p. 105-122

Leemans, R., Cramer, W. P. (1991). The IIASA database for mean monthly values of temperature, precipitation and cloudiness on a global terrestrial grid. RR-91-18, IIASA (International Institute for Applied Systems Analysis), Laxenburg, Austria

Leemans, R., Solomon, A. M. (1993). Modeling the potential change in yield and distribution of the earth's crops under a warmed climate. Clim. Res. 3: 79-96

Manabe, S., Wetherald, R. T. (1987). Reduction in summer soil wetness induced by an increase in atmospheric carbon dioxide. Science 232: 626-628

Mann, L. K. (1986). Changes in soil carbon storage after cultivation. Soil Sci. 142: 279-288

Matthews, E. (1983). Global vegetation and land use: new high resolution data bases for climate studies. J. Climatol. appl. Meteorol. 22: 474-487

Mitchell, J. F. B. (1983). The seasonal response of a general circulation model to changes in $\mathrm{CO}_{2}$ and sea temperature. Q. J. R. Meteorol. Soc. B109: 113-152

Neilson, R. P. (1987). Biotic regionalization and climatic controls in western North America. Vegetatio 70: 135-147

Neilson, R. P., King, G. A., Koerper, G. (1993). Toward a rulebased biome model. Landscape Ecol. 7: 27-43 
Olson, J. S., Watts, J. A., Allison, L. J. (1983). Carbon in live vegetation of major world ecosystems. ORNL 5862. Oak Rudge National Laboratory, Oak Ridge, TN

Overpeck, J. T., Bartlein, P. J., Webb, T ILI (1991). Potential magnitude of future vegetation change in eastern North America: comparisons with the past. Science 254: 692-695

Parry, M. L. Carter, T. R. (1988). The assessment of effects of climatic variations on agriculture: aims, methods and summary of results. In: Parry, M. L., Carter, T. R., Konijn, N. T (eds.) The impact of climatic variations on agriculture, Vol. I, Assessment in cool temperate and cold regions. Kluwer Academic Publishers, Dordrecht, p. 11-95

Prentice, I. C., Cramer, W. P., Harrison, S. P., Leemans, R., Monserud, R. A., Solomon, A. M. (1992a). A global biome model based on plant physiology and dominance, soil properties and climate. J. Biogeogr. 19: 117-134

Prentice, I. C., Solomon, A. M. (1990). Vegetation models and global change. In: Bradley, R. S. (ed.) Global changes of the past. Office for Interdisciplinary Earth Studies, University Corporation for Atmospheric Research, Boulder, CO, p. 365-383

Prentice, I. C., Sykes, M. T. (1993). Vegetation geography and global carbon storage changes. In: Woodwell, G. M. (ed.) Woods Hole Workshop on Biotic Feedbacks in the Global Climate System. Oxford University Press, New York (in press)

Prentice, I. C., Sykes, M. T., Cramer, W. P. (1992b). The possible dynamic response of northern forests to global warming. Global Ecol. Biogeogr. Lett. 1: 129-135

Prentice, I.C., Sykes, M. T., Cramer, W. P. (1993a). A simulation model for the transient effects of climate change on forest landscapes. Ecol. Modelling 65: 51-70

Prentice, I. C., Sykes, M. T., Lautenschlager, M., Harrison, S. P., Denissenko, O., Bartlein, P. J. (1993b). Modeling global vegetation patterns and terrestrial carbon storage at the last glacial maximum. Global Ecol. Biogeogr. Lett. (in press)

Prentice, K. C., Fung, I. Y. (1990). The sensitivity of terrestrial carbon storage to climate change. Nature 346: 48-50

Quay, P. D., Tilbrook, B., Wong, C. S. (1992). Oceanic uptake of fossil fuel $\mathrm{CO}_{2}$ : carbon-13 evidence. Science 256: 74-79

Regehr, D. L., Bazzaz, F. A., Boggess, W. R. (1975). Photosynthesis, transpiration and leaf conductance of Populus deltoides in relation to flooding and drought. Photosynthetica 9: 52-61.

Rosenberg, N. J. (1982). The increasing $\mathrm{CO}_{2}$ in the atmosphere and its implication on agricultural productivity. II. Effects through $\mathrm{CO}_{2}$-induced climate change. Clim. Change 4: $239-254$

Rosenberg, N. J. (1991). Processes for identifying regional influences of and responses to increasing atmospheric $\mathrm{CO}_{2}$ and climate change - the MINK Project. Report I Background and baselines. TR052B, U.S. Dept of Energy, Washington, DC

Sargent, N. E. (1988). Redistribution of the Canadian boreal forest under a warmed climate. Climatol. Bull. 22: 23-34

Schlesinger, M. E., Mitchell, J. F. B. (1985). Model projections of the equilibrium climatic response to increased carbon dioxide. In: MacCracken, M. C., Luther, F. M. (eds.) Projecting the climatic effects of increasing carbon diox- ide. DOE/ER-0237, U.S. Dept of Energy, Washington, DC, p. $81-147$

Schlesınger, M. E., Zhao, Z.-C. (1989). Seasonal climatic changes induced by doubled $\mathrm{CO}_{2}$ as simulated by the OSU atmospheric GCM/mixed-layer ocean model. J Clim. 2: 459-495

Schlesinger, W. H. (1977). Carbon balance in terrestrial detritus. A. Rev. Ecol. Syst. 8: 51-81

Schlesinger, W. H. (1990). Evidence from chronosequence studies of a low carbon-storage potential of soils. Nature 348: $232-234$

Smith, T. M., Shugart, H. H. Jr (1993). The transient response of terrestrial carbon storage to a perturbed climate. Nature 361: $523-526$

Smith, T. M., Weishampel, J. F., Shugart, H. H. Jr, Bonan, G. B. (1992). The response of terrestrial carbon storage to climate change: modeling C dynamics at varying temporal and spatial scales. Wat. Air Soil Pollut. 64: 307-326

Solomon, A. M. (1986). Transient response of forests to $\mathrm{CO}_{2}-$ induced climate change: simulation experiments in eastern North America. Oecologia 68: 567-79

Solomon, A. M., Cramer, W. P. (1993). Biospheric implications of global environmental change. In: Solomon, A. M., Shugart, H. H. Jr (eds.) Vegetation dynamics and global change. Chapman and Hall, New York, p. 25-52

Solomon, A. M., Leemans, R. (1990). Climatic change and landscape ecological response: issues and analysis. In: Boer, M. M., de Groot, R. S. (eds.) Landscape ecological impact of climatic change. IOS Press, Amsterdam, p. $293-316$

Solomon, A. M., Tharp, M. L., West, D. C., Taylor, G. E., Webb, J. M. Trimble, J. L. (1984). Response of unmanaged forests to carbon dioxide-induced climate change: available information, initial tests, and data requirements. TR-009, U.S. Dept of Energy, Washington, DC

Strain, B. R., Cure, J. D. (1985). Direct effects of increasing carbon dioxide on vegetation. DOE/ER-0238, U.S. Dept of Energy, Washington, DC

Tans, P. P., Fung, I. Y., Takahashi, T (1990). Observational constraints on global atmospheric $\mathrm{CO}_{2}$ budget. Science $247 \cdot 1431-1438$

Trabalka, J. R., Reichle, D. E. (1986). The changing carbon cycle: a global analysis. Springer-Verlag, New York

Webb, T III (1987). The appearance and disappearance of major vegetational assemblages: long-term vegetational dynamics in eastern North America. Vegetatio 69: $177-187$

Whittaker, R. H., Likens, G. E. (1975). The biosphere and man. In: Lieth, H., Whittaker, R. H. (eds.) Primary productivity of the biosphere. Ecological studies 14. SpringerVerlag, New York, p. 305-328

Woodward, F. I. (1987). Climate and plant distribution. Cambridge University Press, New York

Zinke, P. J., Stangenberger, A. G., Post, W. M., Emanuel, W. R., Olson, J. S. (1984). Worldwide organic soil carbon and nitrogen data. ORNL/TM-8857, Oak Ridge National Laboratory, Oak Ridge, TN

Zobler, L. (1986). A world soil file for global climate modeling. NASA Technical Memorandum 87802. Goddard Institute for Space Studies, New York 